\title{
Editors' Note to: EDAR, LYPLAL1, PRDM16, PAX3, DKK1, TNFSF12, CACNA2D3, and SUPT3H gene variants influence facial morphology in a Eurasian population
}

\section{Springer Berlin Heidelberg ${ }^{1}$}

Published online: 5 December 2019

(c) Springer-Verlag GmbH Germany, part of Springer Nature 2019

\section{Editors' Note to: Hum Genet 138:681-689}

https://doi.org/10.1007/s00439-019-02023-7

Concerns have been raised about the ethics approval and informed consent procedures related to the research reported in this paper ( $\mathrm{Li}$ et al. 2019). The paper includes the following author declarations: "This study was approved by the Ethics Committee of the Institute of Forensic Science of China, and all individuals provided written informed consent. The participants were all volunteers. The consent was discussed in their native language and the signature was in their native language." Editorial action will be taken as appropriate once an investigation of the concerns is complete and all parties have been given an opportunity to respond in full.

\section{Reference}

Li Y, Zhao W, Li D, Tao X, Xiong Z, Liu J, Zhang W, Ji A, Tang K, Liu F, Li C (2019) EDAR, LYPLAL1, PRDM16, PAX3, DKK1, TNFSF12, CACNA2D3, and SUPT3H gene variants influence facial morphology in a Eurasian population. Hum Genet 138:681689. https://doi.org/10.1007/s00439-019-02023-7

Publisher's Note Springer Nature remains neutral with regard to jurisdictional claims in published maps and institutional affiliations.
Springer Berlin Heidelberg

https://www.springer.com/journal/439

1 Heidelberg, Germany 